\title{
USING RESOURCES FOR SILENT FILM MUSIC
}

\author{
Kendra Preston Leonard
}

Between 1912 and 1929, more than 11,000 commercial motion pictures were made in the United States. We call these works "silent films", but they were accompanied by an enormous body of music, both adapted or arranged from pre-existing compositions and newly written for theatre orchestras, organists, or pianists. A 2013 study by David Pierce and the National Film Preservation Board, in conjunction with the Council on Library and Information Resources (CLIR) and the Library of Congress, found that only thirty percent of these pre-sound films were still extant, with many incomplete or in poor condition, and for a time, music for these films seemed destined to a similar fate: in the 1960s, MetroGoldwyn-Mayer Studios deaccessioned its entire collection of scores and orchestral parts and sent them to a landfill in an event known to industry insiders as the "MGM purge". Since then, however, studios and archives have increasingly valued the historic importance of their silent film music holdings, and scholarly and general interest in these works has grown significantly. In Music for Silent Film: A Guide to North American Resources (MLA Index and Bibliography Series, 39. Middleton, WI: Music Library Association and A-R Editions, 2016), I assemble lists of archives and libraries that house this surviving early movie music, track down publications from the period about how and what to play for the movies, and provide details on more recent secondary sources devoted to the history and analysis of the music used for the silent cinema. In this article, I discuss the various extant resources for research in silent film music and provide two case studies that demonstrate how print and online materials can be used to research a particular genre of silent film music and the reception of a "special score" - an original work designed to be played with just one film-composed for Cecil B. DeMille's Joan the Woman.

As the director of the online Silent Film Sound and Music Archive (http://www.sfsma .org [accessed 16 September 2016]), I have been collecting information regarding the whereabouts of silent film music and recordings for some time. While some of this littlestudied and lesser-heard repertoire is still hidden away in attics, basements, and storage units everywhere, much of what still exists is held in public collections across North America and around the world. Information about this vast body of music, including how and when musicians of the period thought it should be used, can be found in many of the same archives and also online. And although new caches of silent film music are still being discovered-for example, a 2011 find of some 850 scores from a back room in the old

Kendra Preston Leonard is a musicologist and music theorist whose work focuses on women and music in the twentieth and twenty-first centuries; and music and screen history, particularly music and adaptations of Shakespeare. Leonard is the 2016 winner of the Society for American Music Sight and Sound subvention for her collaborative project with pianist Ethan Uslan and the Silent Film Sound and Music Archive, which she directs; a 2016 American Music Research Center Fellowship; and a 2016-2017 Harry Ransom Center Research Fellowship in the Humanities. Her current research project examines the American spiritualist movement and music for the supernatural in silent film.

1. David Pierce, "The Survival of American Silent Feature Films, 1912-1929" (Washington, DC: National Film Preservation Board, with the Council on Library and Information Resources and The Library of Congress, 2013), 1, http://www.loc.gov/film/pdfs/pub158.final_version_sept_2013.pdf, accessed 16 September 2016. 
Birmingham Library in England-performers, scholars, and enthusiasts can now use Music for Silent Film: A Guide to North American Resources to help them locate music collections, contemporary criticism, and other materials.

While working on this bibliography, I found that these documents could tell us far more about music, sound, and the early motion picture than some scholars might imagine. First, though, it is important to understand the many forms of silent film music and what other resources from the period are currently available. Music for silent film came in a variety of formats. Original scores-"special scores"-were commissioned by film companies to accompany a specific film, usually a large-budget production or one featuring stars of the moment. Original scores could be published in full for orchestra, organ, or piano, or abridged to a suite of selections. Joseph Carl Breil's score for D. W. Griffith's epic Intolerance (1916), for example, was published for full orchestra for large cinema houses, as a piano/organ reduction for smaller houses, and in an edited version of selections for piano/organ; this latter format was usually marketed to viewers who wanted to play the music at home. Various collections also suggest that motion-picture houses with smaller budgets used these score abridgements in conjunction with other music to accompany showings of the film.

Original compiled scores were also commissioned for individual films but consisted of preexisting music and sometimes newly composed pieces. When the original score commissioned for The Phantom of the Opera (1925) was not going to be ready in time for the film's premiere, the film's producers commissioned a compiled score from Gustav Hinrichs and Max Winkler. The Hinrichs-Winkler score uses music from Charles Gounod's opera Faust, other extant works, and new material written by Winkler, including scene transitions and atmospheric accompaniment. While complete original scores left little room for improvisation, compiled scores-even those created for an individual film-sometimes contained instructions for performers to improvise as they saw fit on given musical themes, although as the many articles listed in the bibliography can attest, the appropriateness of improvisation was a hotly contested issue in film accompaniment.

Theatre orchestra directors, organists, and pianists also created their own compiled scores. Books of music categorised by mood and collections of music for specific genres-often referred to as "photoplay albums"-offered performers a wide choice of pieces with descriptive titles and suggestions for use. With titles for topics like "airplanes", "dancing", "happiness", "military", and "sorrow", photoplay albums often contain a mix of preexisting art music pieces arranged for piano or organ and original works written for the theatre. These latter pieces are often identifiable through their prosaic titles, such as "Hurry Music", or "Mysterioso". The albums provide not only a snapshot of popular music for film at any given time, but also suggest audience tastes and reception of individual works. One of the most widely used albums, Erno Rapée's Motion Picture Moods (New York: G. Schrimer, 1924), notably includes Frederic Chopin's Prelude op. 28, no. 15 under pieces to use for "monotony", and an excerpt from one of Georges Bizet's L'Arlesienne suites for "orgies". Popular series of photoplay albums include those published by Carl Fischer (the Theatrical Budget Series, the Loose Leaf Motion Picture Collection, and the Carl Fischer Moving Picture Series), Photo-Play Music Co. (the ABC Dramatic Set, ABC Feature Photo-Play Edition, and ABC Photo-Play Concert Edition), Berg's Incidental Series, Schirmer's Photoplay Series, and a number of others.

Theatre musicians also used cue sheets to create the accompaniment for a film. Cue sheets list all of the scenes in the film that they are designed to accompany. For each 
scene or major action in the film, a composer or arranger working for the motion picture studio producing the film would provide a suggested piece of music, either by title alone, or by title and musical incipit of two to four or five measures. Cues also sometimes included the approximate length of each scene and instructions for special sound effects to be used in the scene, such as a train horn or galloping hooves. Cue sheets were designed for performers with a large repertoire at their fingertips and the ability to play and improvise on given themes. The cue sheet for Douglas Fairbanks's The Thief of Bagdad (1924), for example, begins with an incipit from Mendelssohn's incidental music to $A$ Midsummer Night's Dream and directs that it should be played for two and three-quarter minutes while the opening credits are rolling. Performers also created their own cue sheets for films. At the Harry Ransom Center at the University of Texas at Austin, a collection of music and notes once owned by cinema accompanist Hazel M. Burnett contains handwritten cue sheet and notes for an unknown film listing music titles for twenty-three scenes, all drawn from Burnett's personal sheet music. Burnett also created cue sheets by taping together short character pieces cut out of The Etude magazine and writing dialogue or scene descriptions as cues at the top of each new piece or section of a piece.

Thousands of individual pieces were composed for theatre musicians to use in creating compilations and cue sheets. Many of these works, like the newly composed pieces in photoplay albums, bear basic, descriptive titles, but others were more whimsical and had further lives outside of the cinema in homes, dance halls, and vaudeville and serious theatres. There is a considerable amount of repertoire for which it is difficult to tell exactly where and how the music was used. Sheet music for compositions written to accompany a particular film often appear with images from the film on the cover. Popular songs not written for the cinema were also used in silent-film accompaniment, and many theatre musicians' personal collections contain a mixture of both. Well-known songs were also used to satirise or in mock scenes in films, or to provide straightforward commentary on the musical mimesis of the action and events on screen.

Music was also distributed in periodicals for motion picture accompanists. Publications like Jacobs' Orchestra Monthly (Boston: Walter Jacobs, ca. 1910-1941) included reports of what music was being used in what theatres; advice columns for theatre orchestra musicians, conductors, and keyboardists; articles about individual orchestras, performers, and conductors; the complete parts and a piano reduction for two pieces for use in accompanying silent films; and a wealth of advertisements for scores, performers, instructors, instruments, and accessories. Melody (for the Photoplay Musician and the Musical Home) focused on piano and organ arrangements, providing several new pieces of sheet music and reviews of new music in each issue. Other trade magazines and publications ran regular music columns that offered score suggestions, information about different types of organs, accompanying techniques, and events and organisations for cinema performers. One of the earliest of these was The Film Index, which was published from 1908-11. The Film Index maintained a column on "Playing the Pictures" by Clyde Martin, providing cinema accompanists with cue sheets for pictures and advice for playing Edison movies to their best advantage. Other periodicals followed this model, including Exhibitors Herald, Moving (later Motion) Picture News, and Moving Picture World. These employed some of the most prominent film music composers and arrangers of the day, such as S. M. Berg, George Beynon, Ernst Luz, C. W. Long, and Erno Rapée.

Other silent era materials include instruction books and interviews with performers. These books provide practical information on theatre organs, accompanying at the piano, 
and using cue sheets, and often include examples of themes appropriate for a selection of moods and scenes. Many of the texts were designed for pianists wanting to acquire organplaying skills, especially as the popularity of the cinema organ grew and theatre managers and audiences began to desire and expect its wide and more versatile range of accompaniment sounds. In Edith Lang and George West's Musical Accompaniment of Moving Pictures (Boston: Boston Music Co.; New York: G. Schirmer, 1920), for example, the authors explain the parts of the organ and how to use the stops and pedals before discussing musical characterisation, improvisation, and transposition. They also dispense advice on music for different genres (e.g., feature films, cartoons, and newsreels), and using the theatre organ to the maximum, including how to create special effects.

Although few theatre organists, pianists, or other musicians from the silent era are alive today, a number of these practitioners gave interviews-sometimes captured on videoor wrote memoirs about their careers as silent-film accompanists. These interviews and recordings are extraordinary documents that preserve the musicians' techniques, performance philosophies, and personal histories, as well as individual theatre or period practices. Gaylord Carter, who was born in 1905 and began playing for silent films in his teens, became the in-house organist for Sid Grauman's Million Dollar Picture Palace in Los Angeles; he gave several interviews on theatre-organ playing before his death in 2000. Likewise, organist Rosa Rio was interviewed before her death at the age of 107 in 2010. Rio also recorded a number of her improvised and partially improvised scores for films, now available as DVDs.

These resources, as well as the extant films themselves, publicity and marketing materials, and other trade publications, can be used to trace the development of various genres in silent film, examine the predecessors of today's movie scores, explicate public and industry tastes and preferences, and reveal the training, preparation, and approaches of the musicians who composed, arranged, and performed for the silent picture. In the first case below, I examine print music for "spook tales" - the forerunner of the horror film and ghost movie-through the lens of a collection at the University of North Texas and how that information helps us parse performance practices for the genre. In the second case, I use primary sources available online to analyse the critical reception of William Furst's score for Cecil B. Demille's 1916 epic, Joan the Woman, and what that reception can tell us about music for silent film more generally.

\section{Case Study 1: Music for the Supernatural from the University of North Texas Music Library Special Collections}

The University of North Texas (UNT)'s Music Library's Special Collections is home to a collection of about 300 pieces of music written or arranged between 1895 and 1929 for silent film accompaniment. This collection includes a number of pieces exclusive to the UNT Music Library, not found in any other public institution or repository. Even more remarkably, the UNT collection's pieces contain, in many cases, full sets of instrumental parts. With the coming of sound in the late 1920 s, cinema orchestras-usually ensembles of between three and thirty players-disbanded, and many instrumental parts were lost, leaving us with only piano parts for many works of music. The collection is also strong in its representation of works published outside of the United States, particularly from France and Germany; and holds music by accomplished but little-known silent film composers whose works are not preserved in other collections.

The majority of music in the UNT silent film music collection is genre music, such as Gaston Borch’s “Agitato pathetique” (1919); or Erno Rapée’s “Gruesome War Theme” 


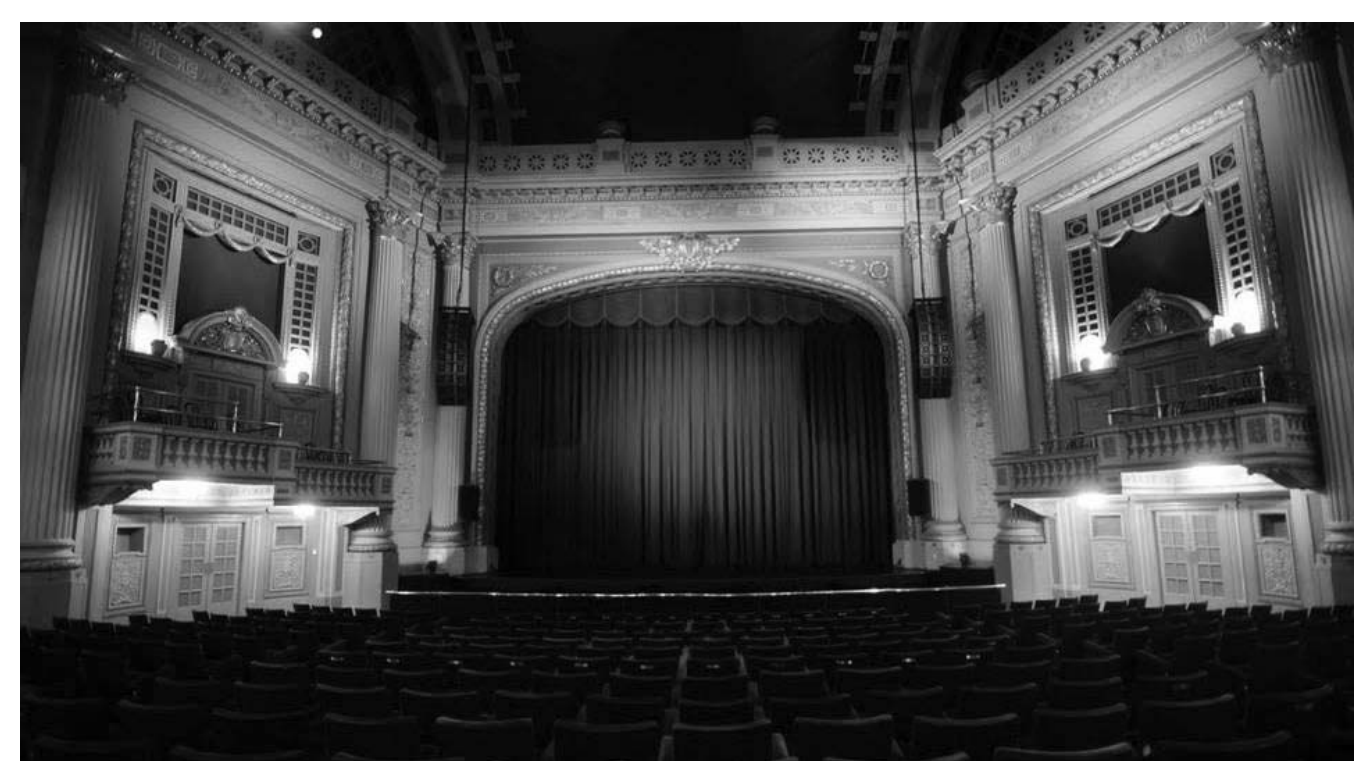

Fig. 1. The Majestic Theater, Dallas, TX.

(1927). But the collection also holds an unusual amount of music for portraying the supernatural on film, including "Gruesome Tales" (Rapée and Axt); "In a Gloomy Forest" (Axt); "Rage: for fiendish anger, sudden outbursts of madness, etc." (Axt); "Mysterious furioso: suitable for infernal and wierd [sic] scenes, witches, etc." (Langey); "Terror, hideous monster, dark mystery" (Zamecnik); and "A Skeleton Jazz Mysterioso" (Breau). Among this subset of works are several pieces for extended scenes, all of which depict manifestations of a human afterlife. Among these are Ellsworth Stevenson's "Phantom Visions; Skeleton Dance" (1920) and Bert A. Anthony's “The Ghost in the Haunted Room” (1924).

It is likely that these pieces came from the library of the Majestic Theater in Dallas (fig. 1), an enormous and ornate cinema seating 2,800 people that opened in $1921^{2}$. The Majestic Theater boasted not only a custom-made Kilgen organ, but also an unusually large pit designed for a robust in-house orchestra for accompanying movies. Past performers' markings in the pieces give us some hints of their performance historymusicians' notes tell us that Anthony's "The Ghost in the Haunted Room”, was used in performance by an ensemble of piano, violin, cello, flute, clarinet, cornet, and timpani, and that parts of it were repeated to extend its length to match a scene in the film. At some point, the piece was designated as $\mathrm{ORCH}$ 00216, suggesting it was part of a larger collection. It is possible that the theatre may have offered themed screenings for Halloween or midnight shows; had a music director interested in filmic and musical special effects or "spook tales" (as early horror or ghost films were termed); or catered to an audience that heavily patronised such fare.

A significant amount of music for the early cinema arranged to match the onscreen action of spook tales drew from and/or was influenced by musical conventions from opera

2. Author's conversation with Morris Martin, 23 April 2016. 
or well-known classical pieces that depicted ghostly or diabolical scenes. Tremolos, the use of very high pitches and harmonics on strings, and bass lines that quoted the Dies irae from the Catholic Requiem Mass were established as hallmarks of the supernatural in the early modern period and were carried forward to music for early cinema. As Mario Bellano has written, the two constants in music for horror are ambiguity and dissonance; thus chromaticism, irregular rhythms, and close intervals were also signifiers of horror, the unnatural, or supernatural. ${ }^{3}$ However, the technical innovations used in creating spook tales required new sensibilities in its accompanimental music. Analysis of Anthony and Stevenson's pieces, viewed in the context of extant spook tales, provides us with an idea of how music for the supernatural needed to be constructed to fit new filmic technologies and give audiences the aural cues they needed and expected in works involving the supernatural.

In his 1896 cinematic spook tale Le Manoir du Diable (1896), French filmmaker Georges Méliès used new film techniques to create illusions of witches, demons, ghosts, and other supernatural figures moving in truly uncanny ways. These apparitions were not the balletic wilis of Giselle, entering elegantly on pointe from the stage wings, nor the urbane Mephistopheles of Faust, appearing from behind a piece of scenery or a trap in the floor with a puff of concealing smoke. Instead, thanks to stop-motion and double-exposure processes, Méliès's characters appeared and disappeared without warning, emerged in blasts of fire from a cauldron, and moved through solid walls.

Such technical filmmaking virtuosity demanded accompanying music that could convey surprise, the mysterious, and the eerie. It also needed to be sectional, so that the accompanist could stop short or repeat material to match the length of a scene. In fact, scenes were not always the same length even in showings in the same picture house; projectionists could run a film at higher or lower speeds as they saw fit, often running films more quickly than directors intended to fit into a specified time, or in order to fit more showings into a day. Such music also needed to be able to be performed by a variety of instruments, ranging from a solo organist or pianist to a larger ensemble. Music for spook tales would have been in constant demand, because playing the same music for each film would have reduced the effect the music had on the audience. Finally, this repertoire needed to contain musical characteristics that hinted at the films' genre without giving away big surprises; therefore, music associated with ghosts and devils from the operatic stage may have been deemed too predictable or well-known, but generic characteristics of this repertoire would be welcomed suggestions of the flavor of each movie.

The new music for spook tales appears to have fit these requirements well. In a 1910 Carl Fisher photoplay collection, works by Mayhew Lake, "Essence Grotesque (for depicting mysterious scenes, grotesque, comedy, etc.)" and "Mysterioso (for depicting stealth, gruesome scenes, etc.)" employ a shared vocabulary with dozens of other similar works of motives, textures, and harmonic structures, closely associating music for scenes of suspense and criminal behavior with the unnatural or grotesque and confirming that spook tales needed music that was not just comprised of tremolos or chromatic passages ${ }^{4}$. By 1920, the concepts of sudden dynamic changes, abrupt or interrupted phrase endings,

3. Marco Bellano, "I Fear What I Hear: The Expression of Horror in Film Music," in Fear Within Melting Boundaries, ed. Lee Baxter and Paula Braescu (Oxford: Inter-Disciplinary Press, 2011), 69-78. E-book.

4. Mayhew Lake, Carl Fischer's Loose Leaf Motion Picture Collection: For Piano Solo (New York: C. Fischer, 1910). 
and the timbres of certain instruments and organ stops, like the flute, clarinet, and horn representing suspense and the supernatural could be accounted as standard for film music. In their 1920 manual on playing for moving pictures, Edith Lang and George West provide a list of repertoire suitable for "scenes of 'mystery, or suppressed alarm, sinister forebodings, ghost scenes, supernatural apparitions, etc.," " stating that such music should be "Misterioso" in nature, incorporating tremolo and either sudden silence or stingers (sudden loud chords) to achieve the best effects for elements of surprise or horror ${ }^{5}$.

Anthony and Stevenson's pieces are deliberately written so as to fill these needs and meet contemporary aesthetics for spook tales. In Stevenson's 1920 "Phantom Visions: Skeleton Dance", the composer calls on musical memories of Saint-Saëns's "Danse Macabre" to reference animated bones. Stevenson marks the piece "misterioso" and calls for special instrumental effects, including the use of col legno (using the wood of the bow), mutes in the brass, muffled drums, "castanets or bones" in the percussion, and a "wind whistle" to create an especially eerie sound. Set in F minor, "Skeleton Dance" starts quietly with staccato quarter notes outlining the tonic, followed by weak beat eighths, often including minor seconds. A long, low horn line moves from steps 5 to 6 and back, not only providing additional emphasis on the key and key relationships but also a funeral marchlike complement to the constant octaves. The pianissimo of the beginning allows Stevenson to surprise the audience with carefully placed accents. As in the "Danse Macabre", Stevenson uses dotted rhythms to create a sense of the dance and a chromatic line to indicate that the piece represents an otherworldly scenario. However, rather than giving the melody to the violin, Death's traditional instrument, Stevenson assigns it-as Lang and West advise-to the winds, starting with the bassoon before handing it off to the oboe, the clarinet, and flute. Swelling dynamics add to the effect of instability and unpredictability, and are mimetic devices that mirror the frequently used in-and-out or swaying movement of ghosts as depicted on film.

"The Ghost in the Haunted Room", published posthumously in 1924, (fig. 2) is marked "Misterioso" and begins in A minor with a series of pianissimo staccato eighths outlining the 7-1-2 scale degrees, followed by "stingers"-forzando B-flats immediately followed by repeated staccato sixteenths in the strings and rolls in the timpani-close neighbors of the tremolo and a motive that would continue in film to represent tip-toeing and suspense. Throughout, quick changes of dynamic from loud to soft suggest surprises, rapid movement or camera cuts, and overall unpredictability. Likewise, the use of chromaticism, a signifier of magic in works by Liszt, Berlioz, Bartok, and Stravinsky, indicates here that normal conditions-those of the natural world-may not apply ${ }^{6}$.

Close dissonances, like the seconds assigned to the violas and cornets or the tritones that support the chromatic passages, provide nearly constant harmonic tension. The use of low tessituras in many parts also suggests the uncertain or eerie, as they do in Edvard Grieg's "Hall of the Mountain King"-a favorite classical piece for accompanying the dangerous-while the unexpected especially high interjections of the flute in $\mathrm{mm}$. 23-24 mimic shrieks. In these first ten measures, Anthony establishes the character or mood of

5. Edith Lang and George West, Musical Accompaniment of Moving Pictures: A Practical Manual for Pianists and Organists and an Exposition of the Principles Underlying the Musical Interpretation of Moving Pictures (Boston: Boston Music Co., 1920), 54-55.

6. David E. Schneider, Bartok, Hungary, and the Renewal of Tradition: Case Studies in the Intersection of Modernity and Nationality (Berkeley: University of California Press, 2006), 133. 


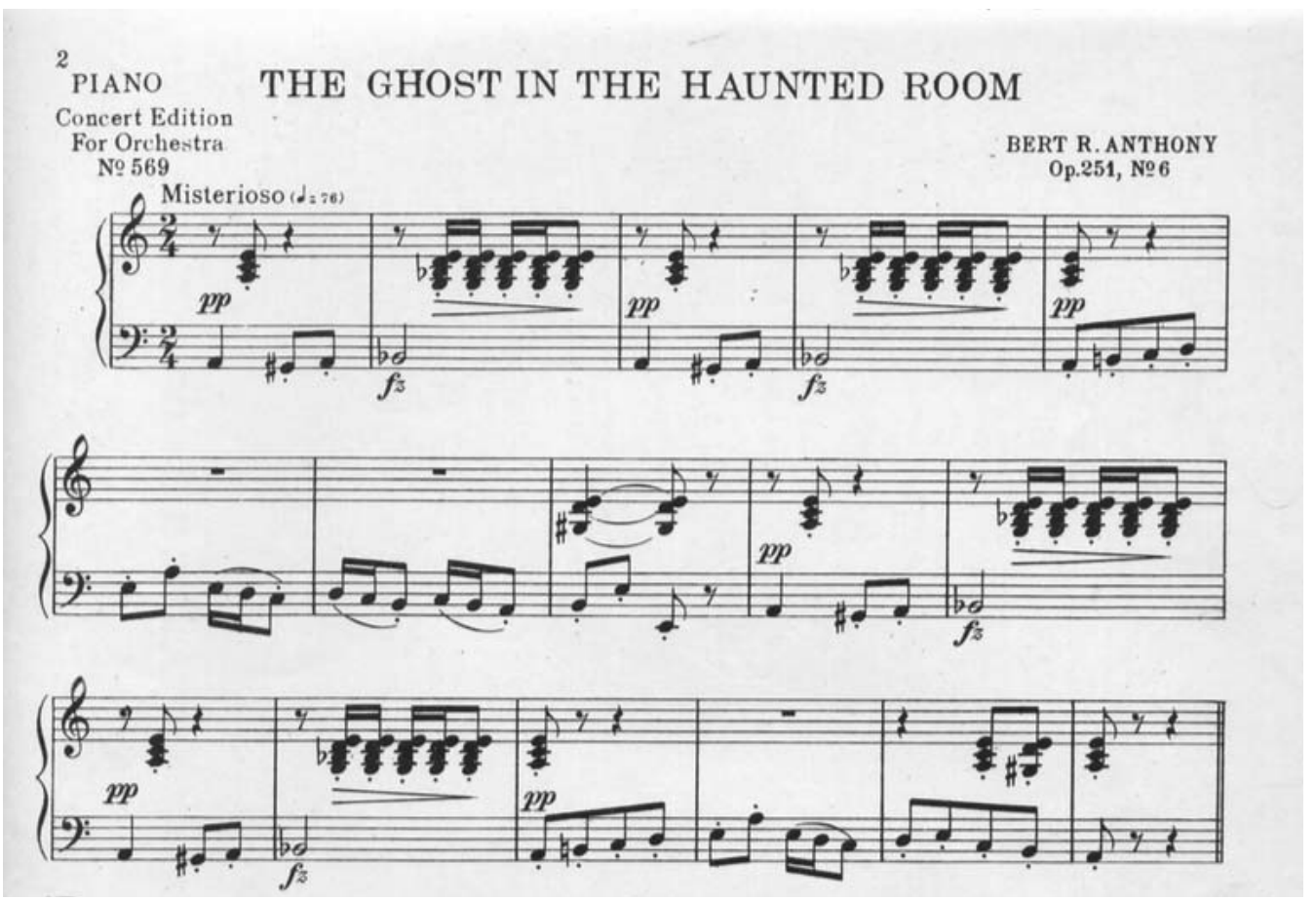

Fig. 2. Bert R. Anthony, "The Ghost in the Haunted Room"

the piece and sets up the audience for a haunting in which supernatural elements may appear and disappear suddenly. The obbligato first violin part provides additional indicia of the developing sound of the spook tale. Anthony sets the tessitura of the part at the bottom of the instrument's range, and twice asks that the performer play on the violin's lowest string in order to create a specific timbre. Again, rising and falling dynamics signify the instability of supernatural beings and add to the atmosphere of liminality between the natural and supernatural worlds. In several places, the viola and flute are paired together in parallel minor thirds, a common marker of sadness-here perhaps redefined as ghostly melancholy - in music and even in speech ${ }^{7}$. Similarly, the violin and clarinet play in unison, creating a timbre that could be interpreted as an attempt to create an otherworldly voice.

In some ways, these pieces are modelled on previous kinds of music for the stage: ballet, melodramatic theatre, and vaudeville. They are designed for mimetic synchronicity, in which action is choreographed to the music-such as in ballet—or the music was written to match the action of an already extant set of motions, as in vaudeville, in which we see music created to mimic popular stage gestures and elements of physical comedy. The rich heritage of these genres informs much of the early music for film, and a great deal of music from those venues was used to accompany silent film; even today, film soundtracks

7. Meagan E. Curtis and Jamshed J. Bharucha, "The Minor Third Communicates Sadness in Apeech, Mirroring its Use in Music”, Emotion 10, no. 3 (June 2010): 335-48, http://www.ncbi.nlm.nih.gov/pubmed /20515223, accessed 16 September 2016. 
often include pre-existing works from pre-cinematic genres, including opera, ballet, and instrumental forms.

But that this repertoire was specifically designated and newly created for the emergent cinema is important in understanding its signification looking forward in respect to the new media of film. "Skeleton Dance" and "The Ghost" were neither excerpts from preexisting music nor ephemeral improvisations, but composed explicitly for the nascent art of the cinema, to be used and re-used as appropriate with a number of films. As accompaniments for the cinematic supernatural, these two pieces have a number of things in common: minor keys; sudden dynamic changes; stepwise, chromatic melody lines; and the use of unusual instruments or instrumental timbres; staccato articulations; and slurred faster passages. The instrumentation is not for full opera or ballet or concert orchestra, but for the kinds of smaller ensembles employed by movie theatres in the pre-integrated sound era. Most if not all of the instrumental parts include cues for other instruments, so that one instrument could double for a missing one in performances. In "Ghost", the viola and clarinet can double for one another; the cornets are given second clarinet cues in the event that there is only one clarinet available; the trombone has bassoon cues; and even the timpani are given cues from the strings in places where, if there are enough drums, they could help fill in for a missing or weak bass line. In "Skeleton Dance", the pianoconductor and violin-conductor parts both include full cues, including expression and timbre markings, for every instrument that carries the primary theme of a dotted rhythm preceded by stepwise ascending eighth note triplets, plus percussion and many supporting instruments. Cues in each instrumental part are extensive and indicate that the publisher anticipated a variety of ensembles using the music. The second violin can fill in for the clarinets; the viola for the bassoon; the cello for the viola or bassoon; the clarinet for the oboe, violin 2, and viola; and so on. The consistency of cues for doubling indicates that cinema orchestras were not just highly variable between individual theatres, but also between performances at the same venue, raising questions of how performance practices varied within specific cinemas due to a multitude of factors including but not limited to theatre location, audience demographics, time of day, time of year, weather, chronolocation during a film's run, the presence or absence of other performances requiring live music at the same time, and many others.

The pieces are sectional and usually non-developmental. This is particularly representative of early cinematic music. Feature films - those of four reels or more-generally offered some sense of continuity, and while narratives tended to be straightforward and chronologically linear, scenes were often very short and moved from one setting to another abruptly, requiring short, sectional pieces of music. The length of scenes and films could also be unpredictable in duration because of varied film speeds. An accompanist might fit Piece A, lasting sixty seconds, to Film A at Cinema A, but at Cinema B, Film A might take an additional ten seconds to show, or, more likely, took ten seconds less. So an accompanist would need to either stretch out Piece A to last an additional ten seconds, play a second section of Piece A to create musical continuity, or find a new piece altogether. Of these, the second scenario seems to have been most common. Not all accompanists were able to screen films in advance; as Rio has testified, she often did her first accompaniment of a film "cold" and tried to develop leitmotifs and themes as she went, developing them further with each additional performance. When a keyboardist who did not improvise played a film without prior screening, sectional music would have been very useful, as performers could have used repeatable or extendable sections in performance 
or jumped to easily identifiable cadences in the music. When music directors were able to view a film before playing for it, they were under pressure to create accompaniments in a very short period of time. Ensembles of three to thirty musicians found in larger movie palaces were not as nimble as single keyboardists, and so cinema orchestra directors favored cinema music with multiple subdivisions and cadence points that could be rapidly edited for films in the few hours between a film's arrival at a theatre and its first screening.

"Skeleton Dance" is divided into sections ending at $\mathrm{mm} .20,37,53$, and 71 , and can be performed with or without a Trio section in which Stevenson embellishes the primary motives of the first part of the piece. There is evidence that at least one conductor also used the trio separately or repeated it in performances. "The Ghost in the Haunted Room" is similarly repetitive and sectioned so that performers using it to accompany a film could easily stop at several different points to fit the projection. The piece can end at mm. 16, 52 , or 70: all of these allowed for a final cadence in the tonic, while ending at the double bar in $\mathrm{m}$. 36 provided for ending on the dominant without resolution. Accompanists could thus fit this piece to a scene to function as a complete and finished encounter, could leave the audience in suspense, or could segue directly into another work for the following title card or scene. In fact, handwritten markings in the piano and first violin parts indicate that this particular set of music was used in circumstances that called for lengthening the music by returning to the beginning from $\mathrm{m} .62$ and playing it through again until the marked end.

Stevenson and Anthony's pieces are only two of the atmospheric works in the UNT Special Collections that employ both pre-existing techniques and new musical ideas regarding sectionality, variable durations, and other flexible elements, such as orchestration, to create an appropriate atmosphere and overall musical background for the supernatural on film. Analysis of other music for spook tales will only add to the data on the large-scale characteristics and mimetic aspects of this repertoire, and using available resources to discover more about the collection's past will inform us as to individual theatres' performance and screening practices.

\section{Case Study 2: The Critical Reception of William Furst's Score for Cecil B. DeMille's Joan the Woman (1916)}

Cecil B. DeMille's film Joan the Woman was released in December 1916, following hot on the heels of D. W. Griffith's blockbuster epics The Birth of a Nation (1915) and Intolerance (1916). DeMille sought to both capitalise on the popularity of long films with historical settings and topics, and to continue creating anti-German war propaganda, with which he had been engaged for several months prior to beginning work on Joan ${ }^{8}$. In Joan, a framing narrative that takes place at the beginning and end of the film presents a British soldier (Wallace Reid) who finds an ancient sword in his trench; when he pulls it from the mud, he receives a highly romanticised vision of Joan of Arc's life and, so encouraged, joins a suicide mission the following day. In the inner narrative, Joan, played by Metropolitan Opera soprano and film actress Geraldine Farrar (fig. 3), rejects romantic overtures made by the soldier's ancestor (also Wallace Reid) and remains true to her heavensent tactical powers, defeats the English at Orleans and then, having been betrayed by the French, dies at the stake.

8. Sumiko Higashi, Cecil B. DeMille and American Culture: The Silent Era (Berkeley: University of California Press, 1994), 123. The film began at thirteen reels and was cut to eight. 


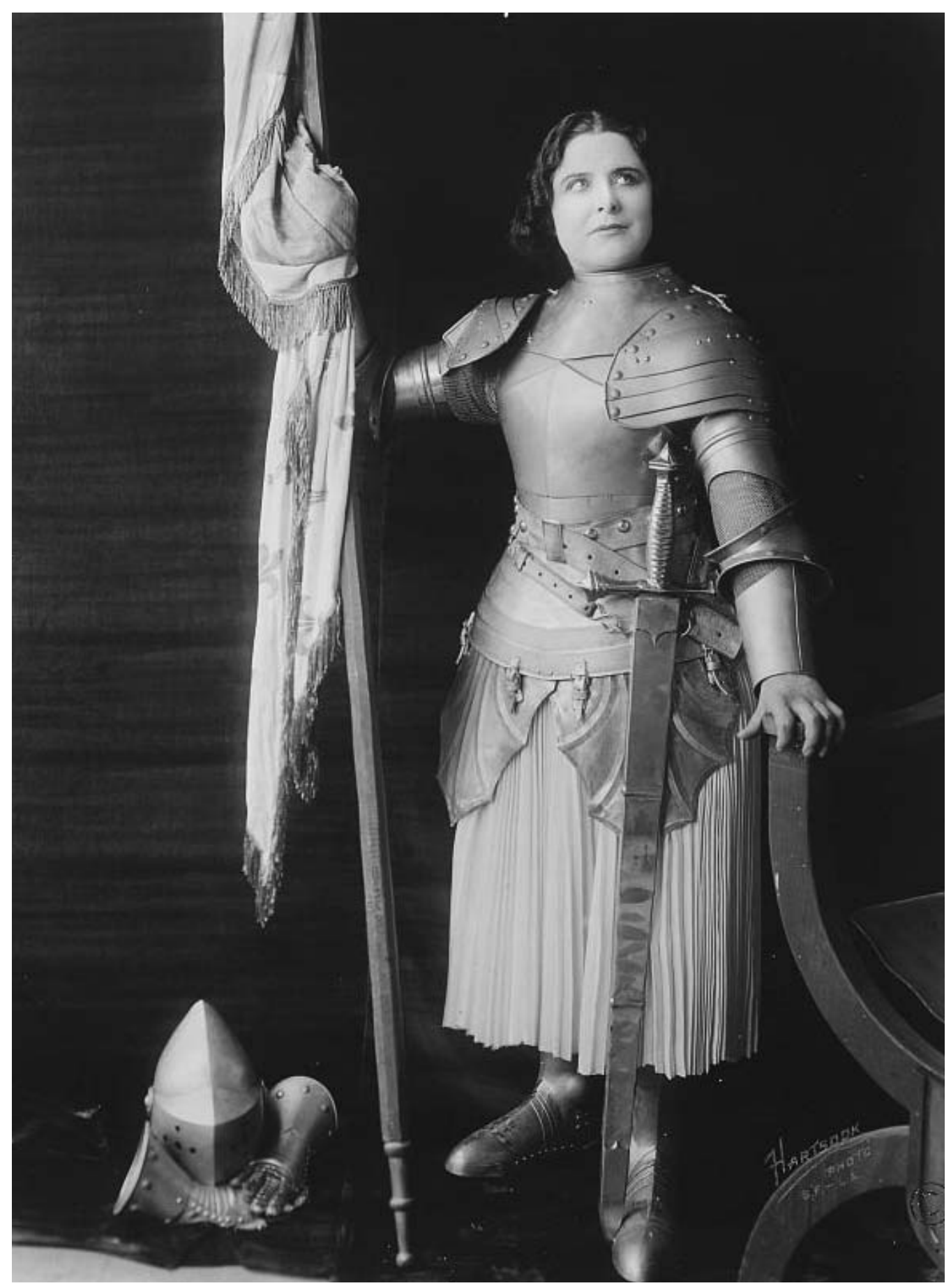

Fig. 3. Geraldine Farrar (1882-1967) as Joan of Arc 
Joan the Woman was a lavish endeavor, with sets and costumes based on illustrations by Maxfield Parish and a wide range of special effects, including the use of color, through both the Wyckoff two-color process and hand-tinting, in several scenes: the spectral Joan appears to the soldier in a glowing, yellowy sepia tint, and the flames that surround Joan at her burning are hand-tinted in rich oranges and yellows.

Joan the Woman was also unrestrained in length, which is an important factor in understanding the music that accompanied it. It was originally filmed in thirteen reelsmore than two hours of running time-but was later cut into two shorter versions, one that as eight reels long and one that was eleven reels. While the long running time emphasised the film's epic, multi-war approach, it was also problematic for exhibitors. Sumiko Higashi found that "theater owners complained that they could not schedule the customary two matinees and two evening shows per day", and so in some cases may have cut out the bookending World War I elements altogether, or sped them up". In Charlotte, North Carolina, the film was reviewed as a "monster production", being eleven reels long and taking two and a half hours to show ${ }^{10}$. Although the film was advertised as eleven reels in the trade magazines, the actual duration of the film varied widely depending on individual cinema practices. Indeed, reviews from multiple locations reveal that various versions of the film, differing in length, were distributed across the United States ${ }^{11}$.

Joan the Woman was just one of several films made about Joan of Arc during the silent era. Although, as Mallory Andrews has found, DeMille's film has been "overshadowed by Carl Theodor Dreyer's indelible The Passion of Joan of Arc (1928)", known for its intimacy and intense close-ups, DeMille's did make a mark, creating "epic, operatic imagery", as is perhaps appropriate for a film starring a Metropolitan Opera star ${ }^{12}$. The introduction of a soldier as a potential love interest for Joan gave DeMille the opportunity to explore a more audience-friendly Joan, one who was not depicted as just a holy vessel, but one with human emotions and emotional conflict. Yet at the same time, Joan's ultimate denial of her wooer provided DeMille with two terrific points of tension for his quasi-historical extravaganza: her noble denial, in which she states (through intertitles): "There is room in each heart but for one love-mine is for France"; and the battle of Orleans, in which Joan must fight opposite her putative lover, who is leading the English army. This human Joan is one who has personal agency, not merely a divinely operated puppet. Robin Blaetz has argued that while Joan is today considered a failure, possibly due to sexism, ageism, and sizeism aimed at Geraldine Farrar, cultural elitism, and/or DeMille's decision to portray a potential romance in Joan's life, the film nonetheless offers us significant information about cinematic and cultural tastes and trends at the time $\mathrm{e}^{13}$. I would suggest that the music composed for and suggested for Joan the Woman likewise opens a window into the history of

9. Higashi, Companion site: http://publishing.cdlib.org/ucpressebooks/view?docId=ft2p300573\&chunk .id=d0e3242\& toc.depth=1\&brand=ucpress, accessed 16 September 2016.

10. The Charlotte News, Charlotte, North Carolina (April 10, 1917), 6, Newspapers.com, https://www .newspapers.com/newspage/61689162/, accessed 16 September 2016.

11. Birchard, Cecil B. DeMille's Hollywood. Moving Picture World 31, no. 5 (February 3, 1917) also states that Joan is in eleven reels.

12. Mallory Andrews, “Instruments of History: Cecil B. DeMille's 'Joan the Woman' on Notebook,” MUBI (https://mubi.com/notebook/posts/instruments-of-history-cecil-b-demille-s-joan-the-woman [accessed 16 September 2016]).

13. Robin Blaetz, Visions of the Maid: Joan of Arc in American Film and Culture (University of Virginia Press, 2001), 62 . 
cinema music, particularly the push for fully original and synchronised scores, as opposed to compiled or improvised scores, and what such scores required of cinema musicians.

Farrar and DeMille had worked together before on their celebrated Carmen (1915). For that film, DeMille apparently originally hired pioneering film music composer, arranger, and promoter Samuel L. Rothafel to create a score from Bizet's opera score, but for reasons that remain unclear, Rothafel passed the job onto Hugo Riesenfeld, another well-known silent cinema music director, composer, and arranger, or had Riesenfeld revise, complete, or orchestrate Rothafel's original ${ }^{14}$. A similar collaborative or multi-creator situation appears to have arisen in the composition of the score for Joan. In August 1916, DeMille began thinking of who might score Joan, and initially proposed Melville Ellis, a musical comedy improviser and composer who had provided on-set mood music for Carmen. Absolutely not, replied Jesse L. Lasky, the film's co-producer, writing

We would not get a practical score such as we would get from a trained composer and arranger. ... if Ellis was allowed to carry out his plan of improvising the score and taking a record of it on a recording phonograph I am sure that whoever arranged and orchestrated Ellis's music would have endless difficulties with the music itself and arguments with Ellis ${ }^{15}$.

Improvisation, it is clear from this discussion, was not acceptable for a film of this magnitude, even if the improvisation was transcribed into notation. An epic movie deserved an epic, traditionally composed score-and not one compiled or arranged from pre-existing music, either. It had to be new, traditionally composed and orchestrated, and specific to this film.

DeMille then commissioned William Furst, an experienced composer of music for stage plays (and who had composed for a previous incarnation of Joan of Arc in live entertainment), to write a full orchestral score that could be easily synched with different projector speeds ${ }^{16}$. The film made road show appearances in eleven major American cities, and the ability to have local orchestras track with potentially varying projection speeds was crucial. Furst in turn hired Robert Russell Bennett to assist him in orchestrating the score $^{17}$. Ideally, this would have generated parts that most cinema performers, whose abilities ranged widely, could play. But when asked to perform the score for a pre-release show, Bennett found that he could not manage the piano reduction of the dense orchestral score and substituted an improvisation instead.

Furst [....] sent me to play the whole score on a grand piano all by myself. At that time I had no idea at all what was in eighty percent of the music. So I sat down to play and watch the picture

14. IMDb (http://www.imdb.com/title/tt0005060/fullcredits?ref_=tt_cl_sm\#cast [accessed 16 September 2016]) gives Rothafel as the "music accompaniment preparer", as does the Boston Globe (October 2, 1915), 1, 4; scholar Gillian Anderson writes that her restored accompaniment to the film is an original score based on Bizet by Riesenfeld deposited at the Library of Congress (http://www.gilliananderson.it/index.php?option=com k2\&view=item\&layout=item\&id=13\&Itemid=29 [accessed 16 September 2016]) and suggests that the "sloppiness of the Riesenfeld arrangement" may have led music directors in cinemas to use other music, or that there were multiple versions of the film or score in circulation.

15. Robert S. Birchard, Cecil B. DeMille's Hollywood (Lexington: University Press of Kentucky, 2009) via Google Books, https://books.google.com/books/about/Cecil_B_DeMille_s_Hollywood.html?id=h8I1dEf7GqIC, accessed 16 September 2016.

16. Higashi, Cecil B. DeMille and American Culture, 117.

17. A copy of a piano-organ reduction for Furst's score survives at the Library of Congress, where it is part of the LC-MOMA Collection and catalogued as Music 3212, Item 75. 
for the first time. I improvised as I had for the first running of the five-cent picture show at 15th and Brooklyn Avenue in Kansas City, but I was not enjoying myself. Just as I was beginning to develop some kind of theme for poor Joan, the pedals of the grand piano fell off ${ }^{18}$.

DeMille, present at the screening, was not pleased. Bennett held that Furst's score for full orchestra was impractical for the smaller ensembles or single keyboardists most theatres would have, and therefore not suited for small venues. At least one publication, the Motion Picture News, agreed. But for large cinemas, the score was accounted a success, and even spurred the creation of the 1917 hit song "Joan of Arc" by Alfred Bryan, Willie Weston, and Jack Wells ${ }^{19}$. Furst's score was performed by twenty-two musicians for its Boston premiere, which was deemed a "notable affair" ${ }^{20}$ In Charlotte, North Carolina, the score was heralded as the "first successful attempt to synchronize a long picture production with a musical score", and stated that DeMille had "established a new kind of relationship so far as the music setting in pictures is concerned", suggesting that the score for The Birth of a Nation by Joseph Carl Breil had not been either the overwhelmingly effective or revolutionary accompaniment it is now often considered to be. In some cities, Joan proved easily as popular as Griffith's epic.

This production [....] has been playing in New York for the past six months to record-breaking crowds at $\$ 2$ per seat and, up to the present week, the attendance records previously held by the Griffith spectacle, The "Birth of a Nation," have been completely shattered by "Joan the Woman," which has as its star the world's greatest opera artist, Miss Geraldine Farrar. This is not the first time Mr. Furst has prepared a music score for a big "Joan of Arc" production, as it was he who composed the music for the "Joan of Arc" pageant in the Harvard stadium in 1907 when Charles Frohman there presented Maude Adams as the immortal "Maid of Orleans"1.

Photoplay magazine also cited Joan the Woman's music as preferable to that of Griffith's most recent production.

William Furst's musical score is a pleasant one, and while it rises to no particular merit, it never angers by its complete inefficiency-as does the "Intolerance" orchestration. Those who criticise [sic] Mr. Furst for his large use of the "Marseillaise" on the ground that it was not composed until hundreds of hears after the winds had scattered Joan's ashes, have no imagination. The "Marseillaise" is not a localized tune; it is a melodic expression of the spirit of France ${ }^{22}$.

The New York-based Music Magazine-Music Courier also found the score effective in its use of Wagnerian leitmotifs and found its musical depiction of the battle scenes particularly noteworthy.

William Furst has composed appropriate music for the photoplay "Joan the Woman," which stars Geraldine Ferrar. He utilizes a pretty love theme throughout the work. Most appropriate is the din of the battle music, and all this is conducted by Louis Maurice in an effective manner.

Moving Picture World's "Music for the Picture" column, written by Clarence E. Sinn and Norman Stuckey, devoted the columns of two issues mostly to discussion of Furst's score,

\footnotetext{
18. Robert Russell Bennett and George Joseph Ferencz, The Broadway Sound: The Autobiography and Selected Essays of Robert Russell Bennett (Rochester: University of Rochester Press, 1999), 45.

19. "Music and the Picture", Motion Picture News (July 14, 1917), 301.

20. Motion Picture News 15, no. 14 (April 7, 1917), 2175.

21. The Charlotte News, Charlotte, North Carolina (April 10, 1917), 6, Newspapers.com, https://www .newspapers.com/newspage/61689162/, accessed 16 September 2016. Punctuation edited for grammatical clarity.

22. Julian Johnson, "The Shadow Stage," Photoplay: The Aristocrat of Motion Picture Magazines (March 1917): 116 .
} 
declaring it "the most noteworthy film score ever heard in New York theaters" and stating that the "association between the composer, star and producer, Cecil B. DeMille, established a new kind of relationship so far as the musical setting of pictures is concerned".

In the first of these columns, Stuckey provides a detailed description of the score from overture ("an orchestral prelude lasting about four minutes") to conclusion ("the Marseillaise, full brass. There is a brief pause and then three sustained chords". ${ }^{23}$ Stuckey attended a New York screening that was accompanied by a forty-piece orchestra of polished professionals; he calls out the performers of the score's oboe, cello, harp, and trumpet solos for special praise and notes the depth that having a tuba in the brass section allows.

Although the orchestra was silent when intertitles were shown, Stuckey suggests that Furst's use of two major themes-a love theme for Joan and Eric and a misterioso that marks the presence of Joan's antagonist, a fanatical monk called L'Oiseleur-creates a sense of musical continuity throughout the entire picture. Each scene, Stuckey notes, is accompanied by "a great variety of tone painting" which he deems "necessary to faithfully portray the many highly dramatic scenes". The music is highly mimetic of the film's visual aspects: an attack on a French village is accompanied by an agitato, followed by another agitato of a different tempo as the soldiers move from killing soldiers to ransacking their homes; when Joan wrests a dagger from a guard and breaks a soldier's sword with it, the percussion and brass mimic the action precisely; Furst employs a hymn-like section for a scene of Charles blessing Joan and religioso music for Joan's prayers. Battles rely heavily on the brass and violins to represent the furor and noise of conflict and shrieking voices; dance music accompanies dances; and trumpets herald the entrances and exits of Charles VII. Marches of both the English and French are accompanied by pieces referencing national tunes-"Rule, Britannia" for the English, and the "Marseillaise" for the French. Joan's walk to the stake is scored with a minor key march, and Stuckey found the music for the fire that consumes her to be "exceptionally descriptive and fine".

Ultimately, Stuckey hails the score as a "symphonic masterpiece", "wrought out in an infinity [sic] of subtle detail of nuance, dynamic contrast and orchestral color" [italics in original]. In the second column on the film's score, Sinn and Stuckey argue that the fully original score-as opposed to a compiled score-is what makes the music for Joan so effective. They write

In all but a few previous productions of this type the music has been "arranged"-that is, an adapter has selected from the world of musical literature what he believed to be suitable themes for various characters and big incidents in the screen drama, and then has stitched them together, orchestrating them when necessary. It is not to be denied that some splendid effects have been obtained by this method, but all too frequently the heroine's theme was taken from some well-known opera or stage music, and the listener was distracted by the inevitable association of the borrowed theme ${ }^{24}$.

They further praise Furst's Wagnerian approach, citing the "complete scheme of musical 'motifs,' which appear in the music simultaneously with the entrance onto the screen of the characters to whom they are ascribed" as the ideal marriage of film and music. Sinn and Stuckey clearly agreed with the anonymous Charlotte citric who thought the score for

23. Norman Stuckey, "Musical Score of Joan the Woman", in "Music for the Picture", Moving Picture World (February 10, 1917), 841.

24. "Furst's Score of 'Joan the Woman,'” in "Music for the Picture”, Moving Picture World (March 3, 1917), 1348. 
Joan better than all previous full-length film scores, including that for Birth of a Nation, which is widely regarded as the first successful full-length original score, despite its inclusion of a number of pre-existing pieces.

It is clear that the music received mostly excellent reviews from those who, like the critics above, heard the score performed with a large cinema orchestra and were actively engaged in promoting original music for film accompaniment. This positive reception of the score from such big-city cultural mavens undoubtedly encouraged other critics and practitioners to view the incorporation of an original, full-length score with a film as a step in the direction towards creating a truly integrated artwork, a view many film music critics shared. For cinemas that did not have full orchestras, however, the score for Joan the Woman was both a musical and logistical problem. Few theatres in smaller towns employed ensembles of the size needed to perform the orchestral score, and the piano reduction-as Bennett's anecdote illustrates-was technically very difficult. In light of this, Motion Picture News offered a cue sheet of existing selections more practical for keyboard accompanists and smaller or less proficient orchestras. The column had previously praised Furst's score as operatic and the "greatest modern composition for the photodrama" 25 . But, the columnists wrote, "Judging from innumerable enquiries which reach our offices, we find that the music score issued by the film manufacturers for 'Joan the Woman' is a little difficult, especially for smaller orchestras" ${ }^{26}$. Thus they constructed a cue sheet with recommendations for performers who could not play the Furst score but who did have access to a number of pre-existing classical and generic pieces.

The cue sheet bears some resemblance to Furst's score in that it also uses the "Marseillaise" and trumpet calls. But it is considerably less holistic. Some compiled scores did assign specific themes to characters or events to create a sense of overall unity, but these suggestions do not; rather, they list a number of disparate works that, while perhaps serving as mimetic accompaniments for individual scenes, present a fragmented and far less coherent soundscape than the designated score. A variety of historiographic styles are interspersed with one another, suggesting the performer move from Massanet to Bach to Grieg to Corelli to Chopin in quick order. Joan is musically represented by the generic "Dramatic Tension No. 1" by Emil Ascher, a "Good Hurry" to be selected by the performer, an unspecified Chopin prelude, Saint-Saëns's "The Swan", the "Credo" from Gounod's St. Cecilia Mass, and other pieces. For the scene of her execution, the writers recommend "a good Grandioso Funeral March (not Chopin)". These cues reveal several things about expectations for accompanists and film music: that accompanists' libraries will include these or very similar well-known or generic pieces, and that accompanists or the members of small orchestras will be able to master these pieces or arrangements quickly and easily; that Baroque and Romantic music will be easily understood as representative of common cinematic tropes, such as personal conflict, military actions, love, and mourning; that audiences would readily accept historiographic discontinuity and a variety of generic music without complaint of ahistoricity or demand for all-new music for each film they viewed; and that, as of 1917, not all cinema managers were convinced of the desire or need for dedicated music for individual films. The reception of Furst's score raises fascinating questions about the composition and performance practices of silent film scores, the abilities and makeup of cinema orchestras in various locations and times

25. "Music and the Picture", Motion Picture News (April 14, 1917), 2397.

26. "Music and the Picture", Motion Picture News (June 23, 1917), 3971. 
in the silent film era, the development of aesthetics and audience tastes and preferences in regard to film music, and the evolution of the title-to-credit full-length film score.

These two cases represent only very brief studies made possible by the deep and wide pool of print and digital resources on silent film music in North American libraries and archives. With the cataloguing of recommendations for thousands of silent films, archives housing sheet music, photoplay albums, and compiled and original scores, as well as other primary sources, there are almost endless opportunities for new and important research on this repertoire. Music for Silent Film: A Guide to North American Resources serves as an introduction and guide to all of these materials. Scholars, performers, and enthusiasts can easily find critical commentary on the music for individual films, on specific silent film composers and performers, on performance practices and advice for performers, on cinema instruments, and on the different philosophical approaches to scoring a film that were under debate during the silent film era. Examination of these and other areas can further our understanding of silent film music and its performance in the context of class, race, age, and gender of audiences; ways in which this music commented on the values and tastes of the time; and other cultural factors of the period.

\section{English Abstract}

While only thirty percent of commercial silent era films survive today, there are still thousands of pieces of music composed and arranged for this medium that remain extant in archives and libraries, including those housed at universities and museums, in rental collections, and online. Music for Silent Film: A Guide to North American Resources lists archives and libraries that house this surviving early movie music, track down publications from the period about how and what to play for the movies, and provide details on more recent secondary sources devoted to the history and analysis of the music used for the silent cinema. These various resources for research in silent film music offer countless topics and materials for examining the use, signification, and preservation of silent film music. This article provides two case studies that demonstrate how print and online materials can be used to research a particular genre of silent film music. The first case examines music for "spook tales" (films involving the supernatural) held by the University of North Texas in the Music Library's Special Collections, and the second details the reception history of the scores for Cecil B. DeMille's 1916 epic film, Joan the Woman.

\section{French Abstract}

Alors que seulement trente pourcent des films de l'époque du cinéma muet commercial subsistent aujourd'hui, il reste toujours des milliers de pièces de musique composées et arrangées pour cette technique cinématographique, et qui sont disponibles en prêt dans les archives et les bibliothèques, y compris dans les universités, les musées, et en ligne. Music for Silent Film: A Guide to North American Resources est un outil qui contient la liste des archives et des bibliothèques qui conservent ces pièces de musique, la localisation des publications de cette époque permettant de connaitre le répertoire et la manière de jouer, et fournit des détails sur des sources récentes qui concernent l'histoire et l'analyse de la musique utilisée pour le cinéma muet. Ces ressources destinées à la recherche sur la musique du cinéma muet offrent d'innombrables sujets et matériels qui permettent d'étudier son utilisation, sa signification et sa conservation. Cet article contient deux études de cas qui démontrent comment les matériels peuvent être utilisés pour rechercher un genre particulier de musique du cinéma muet, qu'il soient disponibles en version imprimée ou en ligne. Le premier cas concerne la musique des « spook tales » (films contenant des éléments surnaturels) conservés dans les collections spéciales de la bibliothèque musicale de l'université University of North Texas. Le second cas présente la réception historique des partitions de musique du film Joan the Woman (1916) de Cecil B. DeMille. 


\section{German Abstract}

Während nur etwa 30 Prozent des Filmmaterials aus der Stummfilmzeit überdauert haben, existieren doch noch tausende Musikwerke, die für Stummfilme komponiert und arrrangiert wurden, in Bibliotheken und Archiven, Universitäten und Museen sowie als Leihmaterial oder online. Der Band Music for Silent Film: A Guide to North American Resources listet Bibliotheken und Archive auf, in deren Beständen frühe Filmmusik bewahrt werden konnte. Außerdem weist er zeitgenössische Veröffentlichungen über Art und Inhalt der zu Filmen zu spielenden Musik nach und beinhaltet Nachweise zu aktueller Sekundärliteratur über Geschichte und Analyse der in Stummfilmen verwendeten Musik. Diese vielfältigen Forschungsquellen zum Stummfilm bieten unzählige Einzelthemen und Materialien zur Untersuchung von Gebrauch, Bedeutung und Erhalt von Stummfilmmusik. Der Beitrag stellt zwei Fallstudien vor, die darstellen, wie sowohl gedruckte als auch Onlinematerialien benutzt werden können, um spezielle Formen von Stummfilmmusik zu erforschen. Der erste Fall untersucht Musik für "Spukgeschichten" (Filme, die übernatürliche Dinge behandeln), die in der Spezialsammlung der Musikbibliothek der University of North Texas existieren, der zweite führt die Rezeptionsgeschichte der Noten für den 1916 entstandenen Spielfilm Joan the Woman von Cecil B. DeMille aus. 